\title{
Aki nyelvjárásban beszél, nem szereti a nyelvtant? Nyelvi attitüdök magyart tanító pedagógusoknál ${ }^{1}$
}

Korábbi munkáimban többször, több szempontból foglalkoztam már a nyelvi alapon történő diszkrimináció jelenségével: fölvázoltam a jelenség vizsgálatával kapcsolatos nehézségeket (Jánk 2018; 2019b), az azok megoldásához kidolgozott mérőeszközt (Jánk 2018), valamint az ezen eszközzel végzett mérés eredményeit is ismertettem különféle fókuszpontokkal, más-más lényegi elemet kiemelve (pl. Jánk 2019a; 2019b; 2019c). Az említett eredmények egy olyan kutatásból származnak, amely 502 leendő és már pályán lévő magyartanárt és tanítót vizsgált. A kutatás fontos tanulságokat hozott nyelvészeti és pedagógiai értelemben egyaránt, ám több olyan aspektusa is volt, amelyekkel legfeljebb érintőlegesen, az említés szintjén foglalkoztam. Ezek közül az egyik legfőbb az, hogy milyen attitüdöt tanúsítanak a vizsgált pedagógusok a különféle nyelvi háttérrel rendelkező tanulókkal szemben.

A vizsgálatból kiderült, hogy mi a különbség, ha egy nyelvjárásban és ha egy standardban beszélö gyerekkel kapcsolatban kell véleményezni a magyartanároknak ugyanazokat a dolgokat, állításokat. Egyebek mellett, hogy mennyire szorgalmasak vagy jó magaviseletüek, mennyire jó gondolkodásúak vagy éppen mennyire szeretik a nyelvtan tantárgyat ezek a gyerekek.

\section{Bevezető és előzmények}

A nyelv elsajátításának elengedhetetlen feltétele a társas környezet, azzal együtt a gyermek számára elérhető nyelvi minta, amelynek sajátosságai nagymértékben meghatározzák a gyermek későbbi kommunikációját. A beszédkapcsolat alakulása a kisgyermek és környezete között függ az adott társadalom értékeitől, hiedelmeitöl, szokásaitól stb., amelyek befolyásolják, mit és hogyan tanul meg; ,a különböző társadalmak más és más helyzetekben, más és más szerepkörökben bátorítják a kisgyermekek nyelvi tevékenységét: ez elősegítheti bizonyos nyelvi elemek, szabályok, nyelvhasználati módok elsajátítását, s hátráltatja másokét" - írja Réger Zita (1990: 81). A felnőtt és gyermek között fennálló beszédkapcsolat, azon belül a nyelv társadalmilag elfogadott használati módjainak átadása fontos része, ugyanakkor eszköze is a kultúra átadásának, a szocializáció folyamatának, vagyis társadalmi attitüdöt, viselkedést, személyiségfejlődést, gondolkodást és világképet formál.

A szülö által közvetített nyelv(változat), az általa használt nyelvi megoldások (különféle nyelvi formák, hangzók, mondatszerkesztési eljárások stb.) képezik a gyerek alapnyelvének ${ }^{2}$ a bázisát. Ahogy a gyermek és környezete között többféle

1 A tanulmány az Emberi Erőforrás Támogatáskezelő által meghirdetett, „Nemzet Fiatal Tehetségeiért Ösztöndíj" címü pályázat (pályázati azonosító: NTP-NFTÖ-19-B-0081) támogatásával valósult meg.

2 Az a nyelvváltozat, amelyet a legkisebb figyelemmel, a legtermészetesebben, legautomatikusabban beszélünk, azaz az anyanyelv azon változata, amelyet elsőként sajátítunk el, és amelynek sajátosságai a későbbiekben is nagy hatással vannak a nyelvhasználatunkra. 
kommunikáció lehetséges, ugyanúgy az egyes nyelvhasználók között is eltérések lesznek a nyelvi szocializációjuktól függően. Ezeket a nyelvi szocializációból fakadó különbségeket az oktatási intézmények, azon belül a pedagógusok gyakran figyelmen kívül hagyják. Ennek következménye, hogy az otthon elsajátított alapnyelv társadalmi előnyök és hátrányok forrásaivá válhat, azaz elösegítheti vagy gátolhatja az érvényesülést és az elörehaladást a társadalmi intézményekben - legelöször az óvodában, majd még jelentősebb mértékben az iskolába belépve.

Az iskola kultúra-újratermelő funkciója biztosítja az újabb generációk számára a társadalom által megtermelt normák, értékek és egyéb kulturális elemek elsajátítását. Ugyanakkor az egyes társadalmakban, ahol különböző kultúrák, nyelvek, szokások, tradíciók, vallások, valamint életformák élnek egymás mellett, illetve keverednek, a kultúra átadásának és a kultúra újratermelésének funkciója új kihívásokat jelent az iskola számára. A modern pedagógiának nem a tanulók családi, nemzetiségi, etnikai identitásának kulturális kötődéseivel szemben kell ellátnia ezt a funkcióját, hanem éppen ezekre alapozva, ezeket felhasználva vagy legalábbis ezen tényezőket figyelembe véve. Azok a pedagógiai eljárások, amelyek nem vesznek tudomást a gyerekek között fennálló különbségekről a gyerekek közötti különbségek fokozódásával, elmélyítésével járnak, ahogy minden olyan tanári tevékenység is, amely határozottan megkülönbözteti az egyes gyerekek által elfogadott és képviselt kultúrák elemeit (vö. Nahalka 2003).

\section{Nyelvi hátrány, nyelvi előítélet és nyelvi diszkrimináció}

A tanulók közötti különbségek közül az egyik legmeghatározóbb a nyelvi differencia, vagyis az otthon elsajátított alapnyelv egyes elemeinek és azok használatának a különbsége: a nyelvi formáknak, az elvont fogalomhasználatnak, a grammatikai elemeknek, a szintaktikai megoldásoknak, a hangtani sajátosságoknak, a nyelvi tudatosságnak stb. az eltérése. Annak ellenére, hogy ez a különbség az oktatási és nevelési folyamatokban elemi jelentőséggel bír, a nyelvhasználók, köztük a pedagógusok kevésbé foglalkoznak ezekkel. Hiába a tény, hogy tudásátadás a nyelv által történik, hiába nyilvánvaló, hogy az egyes pedagógiai tevékenységek (pl. egy utasítás vagy egy szöveges feladat megértése, megoldása) elvégzése olyan meghatározott nyelvi kompetencia és repertoár meglétét, megértését és alkalmazni tudását igényli és előfeltételezi, amelyekkel nem mindenki rendelkezik. Ha ezt nyelvváltozathoz kapcsoljuk, akkor leginkább a standard (más néven köznyelv, sztenderd) változattól való eltérést, pontosabban a standard normájának való meg nem felelést, valamint a standard ismeretének, birtoklásának a hiányát érthetjük rajta (vö. Ludányi 2016; Tolcsvai 2017).

Ha a tanuló nem ismeri jól az adott nyelvváltozatot, akkor nehézségekbe ütközik elsősorban az értés és a problémamegoldás területén. Ilyen esetekben nyelvi hátrányról beszélhetünk, ami szociolingvisztikai értelemben olyan, az egyéni verbális repertoárból eredő, külső (társadalmi-kulturális és szocializációs) okokból származó kommunikációs problémát, ismerethiányt vagy (a többségi társadalom számára nor- 
maként funkcionáló, elvárt nyelvhasználatához képest) eltérést jelent, amely gátolja a tudáselsajátítást, a személyiségfejlődést, az érvényesülést vagy éppen a sikeres problémamegoldást (vö. Zoller 2013; Jánk 2019a: 33). Ha ezt figyelmen kívül hagyjuk, a nyelvi hátrány nyelvi alapú diszkriminációhoz vezet, ami által és azzal párhuzamosan a tanulók közötti társadalmi és nyelvi különbségek tovább fokozódnak, élesednek.

A nyelvi alapú diszkrimináció (más néven lingvicizmus) a nyelvi alapon meghatározott, emberek, embercsoportok közötti diszkrimináció, azaz a beszélöknek a nyelvhasználatuk alapján történő hátrányos vagy előnyös megkülönböztetésének a gyakorlata (Kontra 2005). A nyelvi hátrány természetesen nem feltétlenül von maga után nyelvi alapú diszkriminációt, „csupán” előfeltétele, lehetséges alapja annak, ugyanúgy, ahogy a nyelvi elöítéleteknek, sztereotípiáknak. Ez utóbbi szoros összefüggésben áll a nyelvi attitüdökkel, amelyek az embereknek a nyelvekkel, nyelvváltozatokkal szembeni beállítottságát, az azokhoz való viszonyulását, vélekedését jelölik, vagyis hogy egy adott nyelvre, nyelvváltozatra milyen módon - menynyire kedvezően, pozitívan/kedvezőtlenül, negatívan - reagálnak a nyelvhasználók (Kiss 1995: 135). Erre számos tényező (nyelvi hiedelmek, ideológiák, hagyományok, társas környezet és annak szokásai, elképzelései stb.) van hatással, amelyek egyike az adott nyelvváltozatot magáénak valló társadalmi réteg befolyása.

E három fogalom - a nyelvi hátrány, az elöítélet és a diszkrimináció - a következőképpen függ össze és válik el egymástól. Ahogy a szociológiai és pszichológiai fogalom esetében, úgy a nyelvi értelemben vett hátrányhoz is különféle (nyelvi) előítéletek, sztereotípiák társulnak. Ez még nem jelent nyelvi diszkriminációt, mivel „míg az elöítélet attitűdöket és véleményeket foglal magában, a diszkrimináció egy másik csoport vagy személy iránt ténylegesen tanúsított viselkedést jelent" (Giddens 2008: 381). Vagyis a nyelvi hátrányhoz először nyelvi elöítéletnek kell társulnia, majd ennek a viselkedésben kell megjelennie ahhoz, hogy nyelvi alapon történő diszkriminációról beszélhessünk (vö. Giddens 2008: 380-5; Smith-Mackie 2004: 257-316). A nyelvi hátrány tehát nyelvi másság, ismerethiány, amely gátolja az érvényesülést, a problémamegoldást; a nyelvi elöítélet az ehhez (is) kapcsolódó belső (többnyire negatív) attitüd, beállítódás, vélekedés; míg a nyelvi diszkrimináció az ezek alapján történő kifele történő megnyilvánulás.

\section{A pedagógusok nyelvi előítéletességével kapcsolatos kutatásokról}

Annak ellenére, hogy a nyelvi elöítéletesség és a nyelvi alapú diszkrimináció pedagógiai folyamatokban betöltött szerepe egyike a nyelvészet és a pedagógia leginkább kurrens és releváns kérdéseinek, kutatása - hazai és nemzetközi viszonylatban - kevésbé hangsúlyos. Azok a kutatások, amelyek a témával kapcsolatosak, leginkább a családi háttér és a nyelvi szocializáció kérdéskörére, kapcsolatára, a nyelvi hátrányra vagy a pedagógusok nyelvi attitüdjére fókuszálnak. Ezen területek összekapcsolása azonban csak részben valósul meg, illetve a nyelvi hátrány mint iskolai sikertelenségért felelős tényező csupán korlátozottan, inkább következtetés szint- 
jén fogalmazódik meg (lásd és vö. pl. Bernstein 1971; M. Nádasi 2002; Parapatics 2019). A szóban forgó kutatások közül a dolgozat csupán a téma szempontjából leginkább lényegeseket foglalja össze a továbbiakban: a magyar pedagógusok nyelvi attitüdjére vonatkozó különféle vizsgálatokat.

A magyar pedagógusok nyelvi attitüdjére vonatkozó kutatások száma viszonylag csekély, különösen, ha ezt a pedagógiai értékelés (azon belül: minősítő értékelés) kontextusába helyezzük: mindössze Kiss Jenö (1999) kutatása mutat rá arra, hogy az általános iskolába belépő nyelvjárási beszédü diákok helyesírási hibáinak jelentős hányada a standard és a saját nyelvváltozatuk közötti különbségekből eredeztethető. Ebből kifolyólag a munkámban azokra a kutatásokra fókuszálok, amelyek eredményeiből legalább következtetés szintjén le lehet vonni a témára vonatkoztatható megállapításokat. Az ilyen jellegü magyarországi vizsgálatok mellett azokra a határon túli magyar pedagógusokat érintő kutatásokra is kitérek, amelyeket a saját kutatásomban szereplő országokban (Szlovákia, Románia és Ukrajna) végeztek.

Szabó Tamás Péter (2012) kutatásának eredményeit - habár nem a nyelvi attitüd terminust használja, illetve a témakört a nyelvi javítások és ideológiák szempontjából vizsgálta - vonatkoztathatjuk a magyar pedagógusok nyelvi attitűdjére. A kutatásból arra következtethetünk, hogy a magyar tanárok jelentős része normaközpontú és preskriptív szemléletü, ami a küljavítás gyakorlatán keresztül realizálódik a tanítási órákon (vö. Szabó 2012, 2014). Ezen felül az interjúkorpuszok elemzésénél „erőteljesen tematizálódott a diákok és a tanárok nyelvének különbsége, nyelvinorma-rendszerük konfliktusa" (Szabó 2012: 222).

Ezeken kívül csupán néhány, egyes nyelvjárások és a sztenderd viszonyára némileg vonatkoztatható, azok tanári megítélésével kapcsolatos vizsgálatot végeztek magyar nyelvterületen. A debreceni tanár szakos hallgatók vizsgálatának (Kovács 2014) eredményei hasonló tanulságokat hoztak, mint az előbb említettek: a debreceni nőnemü tanárjelöltek egyharmada számára furcsa a tájszólás, valamint a kétharmaduk szerint az iskolában a magyar nyelvet kell használni, míg a férfi tanárjelöltek több mint fele fontosnak tartja a diákok nyelvi hibáinak azonnali javítását (Kovács 2014). Ez szintén a sztenderd- és normaközpontú pedagógiai (és társadalmi) beállítódás, valamint a preskriptív, hibakereső és -javító szemlélet pedagógiai gyakorlatát igazolja. De nemcsak a pedagógusjelöltek, hanem a pályán lévő Debrecen környéki (keleti területeken élő) pedagógusok is meglehetősen nagy jelentőséget tulajdonítanak a sztenderd nyelvváltozatnak. Nagy (2015) vizsgálatából kiderül, hogy az említett pályán lévő pedagógusok nagyjából 85 százaléka véli úgy, hogy az iskolában kizárólag ,igényes, müvelt köznyelven" kell tanítani, illetve 73 százalékuk szerint ennek használata erkölcsi kérdés. Szintén közel 73 százalék úgy gondolja, hogy a nyelvészek döntik el, hogy mi helyes és mi helytelen a nyelvben, azaz szerintük a nyelvészet ma is eröteljesen elöíró jellegü. Egy kisebb, három dunántúli települést érintő, 20 pedagógus bevonásával készült kérdőíves vizsgálat némileg más szempontból, de ugyanígy a sztenderd magas, míg a nyelvjárás alacsony iskolai presztízsét, illetve az ehhez kötődő sztereotip tanári attitüdöket igazolja. Az adatközlök (egyébként nemcsak a pedagógusok, hanem a tanulók is) a nyelvjárást alacsonyabb iskolai végzettséghez, idősebb korosztályhoz, illetve a határon túli magyarsághoz kötik (Parapatics 2016). 
Az előbbi kutatásokhoz hasonlóan, a sztenderd kultúra erőteljes hatására, működésére utalnak a határon túli magyarságot vizsgáló élőnyelvi kutatások tanulságai is. A szlovákiai magyar pedagógusok körében végezett attitüdvizsgálatok (pl. Kožík 2004), amelyek a szlovákiai magyar nyelvjárásokhoz és a sztenderd változathoz való tanári viszonyulást vizsgálták, azt mutatják, hogy az említett pedagógusok - saját bevallásuk szerint - bár alapvetően pozitívan viszonyulnak a saját nyelvjárásukhoz (75\%-uk például sajnálná, ha kiveszne), a sztenderdnek magasabb presztízst és eszményi értéke(ke)t tulajdonítanak a gyakorlatban: többségük az iskolában a köznyelv használatát várja el, a nyelvjárási jelenségeket pedig javítja.

Ugyanerre engednek következtetni a magyar szakos pedagógusjelöltek és egyetemi hallgatók körében végzett attitüdkutatások (Sándor 2009; Presinszky 2011) eredményei is. Ezekből a vizsgálatokból szintén kiderül, hogy az egyetemi hallgatók többsége beszél valamilyen nyelvjárást, ezt szépnek tartja, ám negatív tapasztalataik is vannak a nyelvjárásukkal kapcsolatosan - ezt ,főként pedagógusaik vagy magyarországi beszélők negatív vélekedése váltotta ki” (Presinszky 2011: 199).

Kárpátalján ugyancsak az előbbi nyelvi beállítódás figyelhető meg a pedagógusok részéről egy ezzel kapcsolatos, 150 (közel felük magyar anyanyelvet tanító) tanárt és tanítót érintő kutatás (Lakatos 2010) tanulságai szerint. A nyelvjárást értéknek, megőrizendő hagyománynak, sőt sokan közülük identitásjelölő eszköznek is tartják, valamint úgy vélik, hogy Kárpátalján beszélnek a legszebben. Mindezek ellenére közel felük (47,3\%) nagyon zavarónak, elfogadhatatlannak tartja az iskolában, tanórán a nyelvjárási beszédet - ebböl az anyanyelvet oktató pedagógusoknak csupán 2,8\%-a (míg a más tárgyakat oktatók 19\%-a) vallja azt, hogy tanórán nem zavarja a nyelvjárási beszéd. Ennek megfelelően az adatközlő pedagógusok közül az anyanyelvet tanítók 83,1 százalékával előfordult már, hogy javította a nyelvjárási beszédet a tanulóknál (vö. Lakatos 2010: 143-68).

Némileg más szempontból közelíti meg a témakört egy erdélyi pedagógusokkal végzett, részben a tanárok nyelvi attitüdjére (általánosságban az iskolák nyelvi tájképére) vonatkozó kutatás (Tódor 2015). Ebben a pedagógusokat arról kérdezték, hogy hogyan viszonyulnak a diákok (anya)nyelvi neveléséhez, milyen nyelvi elemeket nem tartanak elfogadhatónak, melyeket javítják, azaz milyen nevelési szemlélettel rendelkeznek. A pedagógusi narratívák, az explicit nyelvi ideológiák alapján a kutatók három fő viszonyulást határoztak meg, méghozzá: nyelvápolói, standardcentrikus; megengedö-közömbös; valamint határtalanító pedagógusi attitüd. E három közül a legelső, a standardcentrikus viszonyulás (az úgynevezett modellértékü nyelvszemlélet) volt a leggyakoribb az adatok alapján, amelynek elsődleges célja a „helyes, szép, igényes” beszédü magyar nyelvhasználóvá nevelés (vö. Tódor 2015).

Az említett vizsgálatokból látszik, hogy a magyar nyelvterületeken - legyen az Magyarországon vagy a határon túl - a pedagógusok és a pedagógusjelöltek a sztenderd nyelvváltozatnak nagyobb, eszményi értéket és magasabb presztízst tulajdonítanak a gyakorlatban, mint a többi nyelvváltozatnak. Kitüntetett szereppel ruházzák föl azt a többi nyelvváltozathoz képest, és ezt a tanórákon gyakran nyíltan éreztetik a preskriptív szemlélet, illetve a felcserélő módszer alkalmazásával, ugyanis a sztenderdhez való eltérést kijavítandó hibaként kezelik - annak ellenére, hogy 
a nyelvjárásokról mint megőrzendő értékről nyilatkoznak, és a standardot nem feltétlenül sorolják a legszebb, legértékesebb nyelvváltozatok közé. Ennek a látszólagos paradoxonnak a magyarázata valószínüleg az, hogy a pedagógusok elméleti szinten elsajátították ugyan a deskriptív-kontrasztív nyelvészeti szemléletet, ám azt a gyakorlatban csak kevéssé tudják alkalmazni. Tisztában vannak azzal a tanulmányaik alapján, hogy a nyelvjárások megbélyegzése nem helyénvaló, ezt sok esetben hangoztatják is, ám a mindennapokban nem ennek megfelelően járnak el - feltehetően azért, mert igazi fogalmi (konceptuális) váltás nem következik be a gondolkodásukban.

\section{Nyelvi attitüdök négy ország leendő és gyakorló magyartanárainál - módszertan}

A 2018-ban befejeződött kutatásom elsődleges célja az volt, hogy bizonyítsam azt az alaphipotézist, hogy a leendő és már pályán lévő magyar szakos pedagógusoknál bizonyíthatóan jelen van a nyelvi alapú diszkrimináció, méghozzá jelentős mértékben (részletesen lásd Jánk 2019b). A jelenség bizonyításán túl a nyelvi elöítéletességröl is szerettem volna adatokat nyerni, mivel az, ahogy a fentiekböl is látszik, fontos szerepet tölt be a nyelvi diszkrimináció értelmezésében, valamint a nyelvi hátrány pedagógiai folyamatokban történő vizsgálatánál.

A kutatásomban a verbal guise technikához hasonló módszert használtam, amelyet jelentős mértékben átalakítottam a vizsgálati célnak megfelelően, illetve amelyet már többször ismertettem, például a Magyar Nyelvőr korábbi számaiban (lásd Jánk 2018, 2019a). Éppen ezért itt most csak röviden térek ki a módszertanra és a méröeszközre.

A módszer lényege összefoglalva, hogy a pedagógusok (miután kitöltötték az alapadataik felvételére szolgáló háttérkérdőívet) elsőként azt az utasítást kapják, hogy olvassanak el egy rövid, egyszerü és számukra ismert (pl. az ige vagy főnév fogalmáról szóló) tananyagrészlet-vázlatot. Miután ez megtörtént a következő lépésként értékelniük kell egy - az előbbi tananyagrészlet alapján - elmondott feleletet (imitációt). Ez megismétlődik többször a vizsgálat során, más-más tananyagrészletekkel és hangfelvételekkel. Vagyis minden egyes tananyagrészletet egy felelet (hangfelvétel), majd egy értékelő rész (kérdőív) követ. A feleleteket azonban egy-egy általam megírt szöveg alapján mondták el a különböző nyelvváltozattal rendelkező gyermekek, ennek következtében három független változó szerepelt a vizsgálatban, vagyis különbség van az egyes feleleteknél abban, hogy: 1. milyen nyelvváltozatban (standardban vagy nyelvjárásban [konkrétan: keleti palócban]) beszéltek a gyermekek; 2. milyen nyelvhasználattal /nyelvhasználati módban (korlátozott vagy kidolgozott [mondathosszúság és -szerkesztés, önismétlés és változatos szóhasználat szerint]); 3 . a szövegben lévő lényegi információkból mennyit említve (mindet vagy csupán 60\%-át) mondta el a tananyagot.

A vizsgálatba bevont pedagógusoknak többféle értékelést kellett végezniük a feleltekre vonatkozóan. Először egy szituatív értékelést (azaz a felelet érdemjeggyel 
történő értékelését, annak szöveges indoklását, valamint néhány feleletre vonatkozó állítás Likert-skálán történő értékelését), másodszor egy általánosabb, tanulóra (és nem a feleletre) vonatkozó értékelést. ${ }^{3}$ Az utóbbi esetben annyi változás történt, hogy az ötfokú skála értékei mellett megjelent egy új válaszlehetőség, a „nem tudom eldönteni” opció. Ez azért rendkívül lényeges, mert a válaszadó így nincs rákényszerítve egy olyasfajta értékítélet meghozatalára, amely nem tükrözné vissza az ő valódi attitűdjét (szemben a hasonló vizsgálatokkal, ahol mindenképp értékelniük kell az adatközlőknek). Ebben a részben az alábbi hat állítás szerepelt:

1. Olyan diák felelt, aki szereti a magyar nyelv tantárgyat.

2. Olyan diák felelt, aki érti a magyar nyelv tantárgyat.

3. A felelö alapvetően egy jó gondolkodású gyerek.

4. A felelö az osztály egyik legjobb tanulója.

5. A felelö jó magaviseletủ gyerek.

6. A felelö szorgalmas diák.

Amint az látszik, a fentiek mindegyike olyan állitás, amelyek igazságértékét nem lehetséges objektíven megítélni egy tantárgyi felelet alapján, különösen, ha az nem egészen 1 percet tesz ki. Ennek ellenére a vizsgálatban szereplö pedagógusok jelentős része (akár 75-80\%-a) egyes részminták és állítások esetében mégis megkísérelte ezt.

\section{Nyelvi attitüdök négy ország leendő és gyakorló magyartanárainál - eredmények}

A kutatással nyert adatmennyiség nagysága és komplexitása miatt csupán a legfontosabb adatokat ismertetem a továbbiakban. Habár mind a hat állítás eredményeire kitérek, ezt összegezve, a négy ország eredményeiből átlagot vonva teszem, a főbb tendenciákat, jellegzetességeket kiemelve. Fókuszba a nyelvi előítéletesség szempontjából leginkább releváns részadatokat helyezem: egyrészt a „nem tudom eldönteni” válaszok arányát, másrészt az állítással egyetértőkét.

Az adatokat százalékos arányban közlöm, amely a teljes minta, azaz 502 fó eloszlását jelzi. A továbbiakban a következő jelöléseket használom az egyes változók jelölésére: $\mathrm{S}=$ standard nyelvváltozat, $\mathrm{Ny}=$ nyelvjárás; Ko $=$ korlátozott nyelvhasználat, $\mathrm{Ki}=$ kidolgozott nyelvhasználat; $100=$ tartalmilag hibátlan $(100 \%$-os); 60 = tartalmilag hiányos, lényegi információk 60\%-át tartalmazó.

Az első állítás a nyelvtan tantárgy szeretetére vonatkozott, és úgy hangzott, hogy „Olyan diák felelt, aki szereti a magyar nyelv tantárgyat”. Az alábbi (és későbbi) táblázatokban a beérkezett válaszok megoszlása feleletekre lebontva látszik.

3 A nyelvi alapú diszkrimináció elsősorban az egyes feleletekre (feleletimitációkra) adott osztályzatok által mérhető, bizonyítható, míg a nyelvi elöítéletesség a feleletek kapcsán értékelt állításokkal. 
1. táblázat. Olyan diák felelt, aki szereti a magyar nyelv tantárgyat

\begin{tabular}{|l|c|c|c|c|c|}
\hline & $\begin{array}{c}\text { Egyáltalán } \\
\text { nem igaz }\end{array}$ & $\begin{array}{c}\text { Többnyire } \\
\text { nem igaz }\end{array}$ & $\begin{array}{c}\text { Többnyire } \\
\text { igaz }\end{array}$ & $\begin{array}{c}\text { Teljes } \\
\text { mértékben } \\
\text { igaz }\end{array}$ & $\begin{array}{c}\text { Nem tudom } \\
\text { eldönteni }\end{array}$ \\
\hline NyKi100 & $3,4 \%$ & $5,8 \%$ & $28,9 \%$ & $12,0 \%$ & $50,0 \%$ \\
\hline SKo100 & $4,2 \%$ & $8,0 \%$ & $25,7 \%$ & $11,6 \%$ & $50,6 \%$ \\
\hline NyKo100 & $5,8 \%$ & $13,5 \%$ & $23,1 \%$ & $5,2 \%$ & $52,4 \%$ \\
\hline NyKi60 & $2,6 \%$ & $12,0 \%$ & $23,9 \%$ & $12,5 \%$ & $49,0 \%$ \\
\hline SKi60 & $0,8 \%$ & $2,6 \%$ & $19,9 \%$ & $37,3 \%$ & $39,4 \%$ \\
\hline
\end{tabular}

Az adatközlők nagyjából fele választotta a „nem tudom eldönteni” lehetőséget minden feleletnél, míg a másik fele értékelte valamilyen formában a felelőt. Emlékeztetöül: minél kevesebb a „nem tudom eldönteni” válaszok aránya, annál elöítéletesebbek az adatközlők. Vagyis ez azt jelenti - az értékítélet tartalmától függetlenül -, hogy átlagban az adatközlök több mint fele elöítéletes volt nyelvi értelemben ennél az állításnál. Akik pedig értékelték a tanulókat, a legerőteljesebben az ötödikről (SKi60) feltételezték azt, hogy szereti a nyelvtant, méghozzá szignifikánsan nagyobb arányban $(\mathrm{p}<0,05)$, mint a többi diákról. Ez nem véletlen, hiszen az ő felelete hangzott standardban és kidolgozott nyelvhasználatban - az már kevésbé volt jelentős az adatközlök számára, hogy tartalmilag hiányos volt a felelet.

Az első két (Nyki100 és SKo100), valamint a negyedik (NyKi60) felelö közel ugyanolyan megítélés alá esett, jóllehet az utóbbinál magasabb volt a „többnyire nem igaz" válaszok aránya. Mindhárom esetben közös, hogy az állítással (többnyire és teljesen) egyetértők aránya magas, 36 és 41\% közötti. Ez azonban az ötödik felelethez képest alacsonynak számít, míg a harmadik (NyKo100) magasnak, különösen, ha az adatokat csupán a „teljes mértékben igaz” válaszokra vonatkoztatjuk.

A pedagógusok közel felénél megjelenik a nyelvi elöítéletesség, ráadásul ez negatívan érinti a nyelvjárásban és/vagy korlátozott nyelvhasználatban beszélő tanulókat, ám abszolút pozitívan a standard és a kidolgozott nyelvhasználatú gyereket. Viszonyításképpen: a többi diákhoz képest minimum 24,8\%-kal többen gondolják biztosan ez utóbbi tanulóról, hogy szereti is a nyelvtant. Ellenben a kettős nyelvi hátrányban lévő harmadik tanulóról a többi diákhoz képest minimum 6,4\%-kal kevesebben feltételezik ugyanezt, ha pedig a két tanulót összevetjük, a különbség $32,1 \%$. Ennyivel többen vannak meggyőződve arról, hogy a kevesebb nyelvtani ismerettel rendelkező felelő jobban szereti a nyelvtan tantárgyat, mivel nyelvileg meggyőzőbb.

A második állítás a tantárgy értésére vonatkozott, az alábbi eloszlást mutatva az egyes válaszokat illetően: 
2. táblázat. Olyan diák felelt, aki érti a magyar nyelv tantárgyat

\begin{tabular}{|l|c|c|c|c|c|}
\hline & $\begin{array}{c}\text { Egyáltalán nem } \\
\text { igaz }\end{array}$ & $\begin{array}{c}\text { Többnyire } \\
\text { nem igaz }\end{array}$ & $\begin{array}{c}\text { Többnyire } \\
\text { igaz }\end{array}$ & $\begin{array}{c}\text { Teljes } \\
\text { mértékben igaz }\end{array}$ & $\begin{array}{c}\text { Nem } \\
\text { tudom } \\
\text { eldönteni }\end{array}$ \\
\hline NyKi100 & $5,0 \%$ & $7,2 \%$ & $38,8 \%$ & $22,5 \%$ & $26,5 \%$ \\
\hline SKo100 & $4,8 \%$ & $6,6 \%$ & $42,2 \%$ & $24,7 \%$ & $21,7 \%$ \\
\hline NyKo100 & $8,2 \%$ & $15,3 \%$ & $37,8 \%$ & $11,4 \%$ & $27,3 \%$ \\
\hline NyKi60 & $2,6 \%$ & $12,2 \%$ & $40,8 \%$ & $20,9 \%$ & $23,5 \%$ \\
\hline SKi60 & $1,4 \%$ & $5,6 \%$ & $26,5 \%$ & $46,8 \%$ & $19,7 \%$ \\
\hline
\end{tabular}

A vizsgált magyartanárok (felelettől függően) 70-80\%-a vélte úgy, hogy képes egy mindössze egyetlen perc hosszúságú hanganyag alapján megállapítani, hogy a tanuló mennyire érti az adott tantárgyat. Ez kétségtelenül a nyelvi elöítéletesség erőteljes jelenlétét támasztja alá, ugyanúgy, mint maguk a konkrét értékelések.

Az adatközlők itt is az ötödik felelőt ítélték meg a legkedvezőbben, ismét szignifikánsan $(\mathrm{p}<0,01)$ nagyobb arányban, mint az összes többi tanulót. 46,8\% teljes mértékben igaznak tartotta az állítást ennél a gyermeknél, míg az első kettőnél (NyKi100 és SKi100) csupán 22,5-24,7\%, a negyediknél (NyKi60) 20,9\%, míg a harmadiknál (NyKo100) csupán 11,4\%. A helyzet hasonló: ha a többnyire igaz állítások arányát is beszámítjuk, hiszen csupán az utolsó felelet esetében releváns az eltérés a százalékarányokban. Az adatokból az is kiolvasható, hogy szemben az előző állítással, a nyelvjárás itt nagyobb hátrányt jelent, mint a korlátozott nyelvhasználat (persze a kettő ismét együttesen képezi a legnagyobb hátrányt).

A nyelvi elöítéletesség tehát ismét a standard nyelvváltozatú és kidolgozott nyelvhasználatú gyereknek kedvez, a nyelvjárási és korlátozott nyelvhasználatúnak viszont hatalmas hátrányt jelent. Hasonló elöítéletesség jelentkezett a felelő gondolkodására vonatkozó állítás esetében is, amint az az alábbi táblázatból látszik:

3. táblázat. A felelő alapvetően egy jó gondolkodású gyerek

\begin{tabular}{|l|r|r|r|r|r|}
\hline & $\begin{array}{c}\text { Egyáltalán } \\
\text { nem igaz }\end{array}$ & $\begin{array}{c}\text { Többnyire } \\
\text { nem igaz }\end{array}$ & \multicolumn{1}{c|}{$\begin{array}{c}\text { Többnyire } \\
\text { igaz }\end{array}$} & $\begin{array}{c}\text { Teljes } \\
\text { mértékben } \\
\text { igaz }\end{array}$ & $\begin{array}{l}\text { Nem tudom } \\
\text { eldönteni }\end{array}$ \\
\hline NyKi100 & $2,0 \%$ & $6,6 \%$ & $34,7 \%$ & $29,9 \%$ & $26,9 \%$ \\
\hline SKo100 & $2,8 \%$ & $6,2 \%$ & $39,0 \%$ & $29,3 \%$ & $22,7 \%$ \\
\hline NyKo100 & $5,6 \%$ & $11,6 \%$ & $36,1 \%$ & $17,9 \%$ & $28,9 \%$ \\
\hline NyKi60 & $1,8 \%$ & $5,6 \%$ & $38,2 \%$ & $26,7 \%$ & $27,7 \%$ \\
\hline SKi60 & $0,6 \%$ & $2,6 \%$ & $22,9 \%$ & $55,4 \%$ & $18,5 \%$ \\
\hline
\end{tabular}

Amint az a fenti táblázat adataiból kitünik, a „nem tudom eldönteni” válaszok aránya jócskán 30\% alatt van minden esetben, azaz a vizsgálatban szereplő pedagógusok több mint kétharmada volt elöítéletes nyelvileg.

A nyelvjárási feleleteknél az adatközlök kicsivel kevesebb, mint kétharmada (kb. 71-73\%) érezte úgy, hogy a tanulókról meg tudják állapítani, hogy jó gondolko- 
dásúak vagy sem, míg a standard feleleteknél valamivel több, mint kétharmaduk (77-81,5\%).

Az adatközlök több mint fele $(55,4 \%)$ az ötödik (SKi60) tanulóról feltételezte a leginkább, hogy jó gondolkodású, a legkevésbé a harmadikról (NyKo100), mindkettő szignifikánsan $(\mathrm{p}<0,05)$ kedvezőbb megítélés a többi esethez képest, csak az előjel más. Külön érdemes megfigyelni, az állítást (egyáltalán és többnyire) nem igaznak tartók arányát. A harmadik feleletnél a többihez képest kiugróan magas ez az arány $(17,2 \%)$, míg az utolsó feleletnél jóval alacsonyabb $(3,2)$ a másik négyhez viszonyítva. Ez azt jelenti, hogy a nyelvjárásban és korlátozott nyelvhasználattal felelő tanulóról a többiekhez képest kétszer annyian feltételezik, hogy nem egy jó gondolkodású gyerek, míg a standard és kidolgozott nyelvhasználatúról háromszor kevesebben vélik ugyanezt.

A negyedik (A felelő az osztály legjobb tanulója) állítás értékelésénél is erőteljes nyelvi elöítéletesség volt megfigyelhető a válaszok megoszlása alapján, amit a következő táblázat szemléltet:

4. táblázat. A felelő az osztály egyik legjobb tanulója

\begin{tabular}{|l|c|c|c|c|c|}
\hline & $\begin{array}{c}\text { Egyáltalán } \\
\text { nem igaz }\end{array}$ & $\begin{array}{c}\text { Többnyire } \\
\text { nem igaz }\end{array}$ & $\begin{array}{c}\text { Többnyire } \\
\text { igaz }\end{array}$ & $\begin{array}{c}\text { Teljes } \\
\text { mértékben } \\
\text { igaz }\end{array}$ & $\begin{array}{c}\text { Nem tudom } \\
\text { eldönteni }\end{array}$ \\
\hline NyKi100 & $2,2 \%$ & $6,0 \%$ & $29,7 \%$ & $18,7 \%$ & $43,4 \%$ \\
\hline SKo100 & $3,8 \%$ & $11,6 \%$ & $28,1 \%$ & $10,8 \%$ & $45,8 \%$ \\
\hline NyKo100 & $9,8 \%$ & $18,5 \%$ & $19,3 \%$ & $6,8 \%$ & $45,6 \%$ \\
\hline NyKi60 & $3,8 \%$ & $13,9 \%$ & $20,9 \%$ & $10,4 \%$ & $51,0 \%$ \\
\hline SKi60 & $0,8 \%$ & $2,2 \%$ & $18,7 \%$ & $43,6 \%$ & $34,7 \%$ \\
\hline
\end{tabular}

Ennél az állításnál a magyartanárok minimum 49\%-a nyilvánított véleményt abban, hogy az adott gyerek az osztály legjobb tanulói közé tartozik-e, vagy sem. Ezt ismét az ötödik (SKi60) felelöről feltételezték a leginkább a pedagógusok: a teljes minta 43,6\%-a vélte igaznak teljes mértékben az állítást, míg a másik négy tanuló esetében nagyjából összesítve ugyanez a válaszarány. Ez a különbség amellett, hogy szignifikáns $(\mathrm{p}<0,01)$, az összes állításnál tapasztaltakhoz képest a leglátványosabb és leginkább sokatmondó is, hiszen jól mutatja az nyelvi elöítéletesség mértékét és müködését.

A második legjobb megítélést az első (Nyki100) felelő kapta, míg a legkevésbé kedvezőt a harmadik (Nyko100), míg a második (SKo100) és negyedik (NyKi60) felelök megítélése a kettő között helyezkedett el (a másodiké valamivel kedvezőbb). Ez több aspektusból is rendkívül problematikus. Egyrészt azért, mert a három azonos felkészültséggel rendelkező tanuló között történik egy diszkriminatív és igazságtalan sorrendképzés, amelyben az jár rosszul, aki eleve hátrányosabb helyzetből indul. Másrészt azért, mert ahogy az adatokból látszik, a nyelvi hátrány nem felülírható, nem mérsékelhető a szorgalom és a megszerzett tudás által, ugyanis a nyelvi elöítéletesség jóval erőteljesebben müködik, mintsem hogy ez a nyelvi hátrányos helyzet felülíródhasson a tanári gondolkodásban. 
A standard nyelvváltozatú és kidolgozott nyelvhasználatú diák a teljesítményétől függetlenül a többi tanuló elé sorolódik a képzeletbeli eminens tanulók rangsorában. Ezzel szemben a mindent megtanuló, csak éppen ezt nyelvjárásban és korlátozott nyelvhasználatban elöadó gyermek ugyanezen rangsor másik oldalára kerül, a „rossz tanulók” kategóriába. Különösen akkor, ha az állítással egyet nem értook arányát is számításba vesszük, ami újból az említett két feleltnél kiugró (különböző irányba, pozitív és negatív értelemben), és összevetve a kettőt meglehetősen markáns különbség mutatható ki: a harmadik feleletnél 28,3\% azoknak az aránya, akik nem sorolják a diákot az osztály legjobbjai közé, viszont az ötödik feleletnél ez mindössze 3\% (a többi feleletnél 8 és18\% közötti ez az érték).

A tanuló magaviseletére vonatkozó állítás esetében bizonyos tekintetben pontosan az előbbi jellegzetességek ismétlődtek meg, ám volt néhány lényegibb változás is az arányok és értékek területén:

5. táblázat. A felelő jó magaviseletű gyerek

\begin{tabular}{|l|c|c|c|c|c|}
\hline & $\begin{array}{c}\text { Egyáltalán } \\
\text { nem igaz }\end{array}$ & $\begin{array}{c}\text { Többnyire } \\
\text { nem igaz }\end{array}$ & $\begin{array}{c}\text { Többnyire } \\
\text { igaz }\end{array}$ & $\begin{array}{c}\text { Teljes } \\
\text { mértékben } \\
\text { igaz }\end{array}$ & $\begin{array}{c}\text { Nem tudom } \\
\text { eldönteni }\end{array}$ \\
\hline NyKi100 & $0,8 \%$ & $2,0 \%$ & $24,7 \%$ & $18,5 \%$ & $54,0 \%$ \\
\hline SKo100 & $1,6 \%$ & $3,8 \%$ & $24,1 \%$ & $10,8 \%$ & $59,8 \%$ \\
\hline NyKo100 & $1,2 \%$ & $4,8 \%$ & $23,5 \%$ & $10,6 \%$ & $60,0 \%$ \\
\hline NyKi60 & $1,2 \%$ & $2,6 \%$ & $20,5 \%$ & $13,5 \%$ & $62,2 \%$ \\
\hline SKi60 & $0,0 \%$ & $0,6 \%$ & $18,7 \%$ & $31,9 \%$ & $48,8 \%$ \\
\hline
\end{tabular}

A „,nem tudom eldönteni” lehetőséget ezúttal az adatközlők átlagban kb. 57\%-a választotta, ami alapján kijelenthető, hogy a nyelvi elöítéletesség nem olyan nagymértékü a magaviselettel kapcsolatosan, mint a többi személyiségjegyre, tulajdonságra vonatkozóan (de természetesen még ebben az esetben is jelentős). Az arányokat tekintve nagyjából ugyanaz a helyzet, mint a korábbi állítások esetében: a legjobb értékelést ismételten az ötödik (SKi60) felelö érte el, őt az első (NyKi100) követte, majd a fennmaradó három felelet, amelyek között nem volt jelentős a különbség. Ez az eddigi állításokhoz viszonyítva változás, ugyanis a harmadik (NyKo100) felelet mindig egyértelmüen a legkedvezőtlenebb megítélés alá esett. Ezúttal azonban ez a felelet csupán nagyon minimális különbséggel került a rangsor aljára, néhány tized különbséggel a második (SKi100) felelethez képest. Ez arra utal, hogy a magaviselet megítélésénél inkább a nyelvhasználat válik súlyozott szemponttá szemben a nyelvváltozattal és tartalmi tudással, bár ez inkább feltevés, mintsem statisztikailag igazolt álláspont.

Mindazonáltal itt sem beszélhetünk a nyelvi elöítéletesség elmaradásáról, csupán mérséklődéséröl, hiszen az adatközlők 40-50\% értékelte a feleletet. Ezen belül a kettős nyelvi előnnyel rendelkező tanulót ítélték meg ismét a legkedvezőbben, míg a kettős nyelvi hátrányban lévőt a legkedvezőtlenebbül.

Az utolsó, a tanuló szorgalmára vonatkozó állítás értékelésénél a magyartanárok újból erőteljes nyelvi elöítéletességet tanúsítottak, bár a standard nyelvváltozatból és kidolgozott nyelvhasználatból származó előny valamivel csökkent. 
6. táblázat. A felelő szorgalmas diák

\begin{tabular}{|l|c|c|c|c|c|}
\hline & $\begin{array}{c}\text { Egyáltalán } \\
\text { nem igaz }\end{array}$ & $\begin{array}{c}\text { Többnyire } \\
\text { nem igaz }\end{array}$ & $\begin{array}{c}\text { Többnyire } \\
\text { igaz }\end{array}$ & $\begin{array}{c}\text { Teljes } \\
\text { mértékben } \\
\text { igaz }\end{array}$ & $\begin{array}{c}\text { Nem tudom } \\
\text { eldönteni }\end{array}$ \\
\hline NyKi100 & $0,0 \%$ & $1,6 \%$ & $32,9 \%$ & $45,4 \%$ & $20,1 \%$ \\
\hline SKo100 & $1,2 \%$ & $4,8 \%$ & $42,2 \%$ & $24,5 \%$ & $27,3 \%$ \\
\hline NyKo100 & $3,4 \%$ & $7,2 \%$ & $37,3 \%$ & $20,5 \%$ & $31,7 \%$ \\
\hline NyKi60 & $2,2 \%$ & $9,2 \%$ & $29,9 \%$ & $22,9 \%$ & $35,9 \%$ \\
\hline SKi60 & $0,4 \%$ & $2,4 \%$ & $23,1 \%$ & $47,8 \%$ & $26,3 \%$ \\
\hline
\end{tabular}

Az összesített százalékarányok rendkívül erős nyelvi előítéletességről árulkodnak. Az adatközlők értékelésében a „nem tudom eldönteni” válaszok száma meglehetősen alacsony volt, a pedagógusok legfeljebb 35\%-a élt ezzel a lehetőséggel, míg átlagban kb. 28\%-uk: csupán ennyien gondolták úgy, hogy egy rövid hanganyagból nem lehet vagy nem tudnak következtetni a tanuló szorgalmára. Az a nagyjából 70-80\%, aki viszont az ellenkezőjét gondolta, ezúttal is az ötödik felelőt vélte a leginkább szorgalmasnak, jóllehet, csak néhány százalékos eltéréssel kedvezőtlenebb az első (NyKi100) tanuló ilyen szempontú megítélése, így ez összességében nem is jelent szignifikáns különbséget.

\section{6. Összegzés és kitekintés}

A fentiekben ismertetett kutatás eredményei egyrészt azt bizonyítják, hogy a több mint 500 vizsgált leendő és már pályán lévő magyartanár jelentős része elöítéletes nyelvileg, ami többféleképpen is megnyilvánul: a nyelvjárással és a korlátozott nyelvhasználattal kapcsolatos negatív nyelvi attitüdben éppúgy, mint a standard nyelvváltozat irányába mutatott pozitív nyelvi attitüdben. Másrészt az eredmények erőteljesen azt sugallják, hogy az iskolai élet során elemi jelentőséggel bír a gyermekek által használt nyelv, és nem pusztán a kommunikációhoz szorosan kötődő területeket illetően. Sokkal általánosabb szinten, sokkal kiterjedtebben befolyásolja a pedagógus tanulókról alkotott képét az általuk birtokolt nyelvváltozat és nyelvhasználat, és ez alapján joggal vonhatjuk le a következtetést, hogy összességében az iskolai eredményesség egyik meghatározó tényezője a nyelv.

Az adatok egyértelmúen igazolták, hogy a vizsgált pedagógusok a) nyelvileg elöítéletesek; b) nyelvjárással kapcsolatos attitüdjük negatív, míg a standard nyelvváltozattal kapcsolatban pozitív; c) az értékelésüket sokkal inkább a nyelvi tényezőkre, mintsem a tartalmi tudásra alapozzák, még olyan esetekben is (pl. a szorgalom), ahol ez éppen fordítva indokolt. Ezt többek között a „,nem tudom eldönteni” válaszok alacsony száma bizonyítja, ami csupán egyetlen állításnál haladta meg az 50\%-ot: a tanuló magaviseletével kapcsolatban érezték úgy a legkevésbé a pedagógusok, hogy képesek e tulajdonságra vonatkozó következtetéseket levonni. A többi állításnál jóval magasabb volt azok aránya, akik úgy vélték, hogy képesek egy mindössze egyperces felelet alapján megítélni a tanuló különféle tulajdonságait, személyiségjegyeit. A min- 
tában szereplök átlagban kb. 60-70\%-a gondolta úgy, hogy az adott felelöröl képes megállapítani, hogy az osztály legjobb tanulói közé tartozik-e, vagy sem.

Az elöbbiek másik oldala, hogy egyetlen olyan állítás sem volt, amelynél a leendő és gyakorló magyartanárok ne a standard nyelvváltozatban és a kidolgozott nyelvhasználattal felelő diákot ítélték volna meg a legkedvezőbben - a hiányos felelete ellenére. Ahogy olyan állítás sem, ahol a nyelvjárásban beszélő és korlátozott nyelvhasználattal rendelkező tanuló ne a legrosszabb megítélést kapta volna az összes diák közül - hiába produkált tartalmilag tökéletes feleletet. Az adatok továbbá azt mutatják, hogy egyik (nyelvváltozati) vagy másik (nyelvhasználati) nyelvi hátrány valamelyest mérséklödik, amennyiben valamilyen nyelvi elöny (standard nyelvváltozat vagy kidolgozott nyelvhasználat) áll mellette, annyira azonban nem, hogy elérje a kettős nyelvi előny következtében kialakuló pozitív nyelvi megítélés szintjét.

\section{SZAKIRODALOM}

Bernstein, Basil 1971. Class, codes and control. Volume I.: Theoretical Studies Towards a Sociology of Language. Routledge and Kegan Paul, London - New York.

Giddens, Anthony 2008. Szociológia (Második kiadás). Osiris Kiadó, Budapest.

Jánk István 2018. A nyelvi alapú diszkrimináció vizsgálatának módszertani korlátai és lehetőségei. Magyar Nyelvőr 142: 150-69.

Jánk, István 2019a. Lingvicizmus a Kárpát-medence négy országának gyakorló és leendő magyartanárainál. Magyar Nyelvőr 143: 31-45.

Jánk István 2019b. Nyelvi elöitélet és diszkrimináció a magyartanári értékelésben. Nyitrai Konstantin Filozófus Egyetem Közép-európai Tanulmányok Kara, Nyitra.

Jánk, István 2019c. Nyelvi diszkrimináció a romániai magyartanárok értékelésében. Magiszter XVII/1: 68-81.

Kiss Jenő 1995. Társadalom és nyelvhasználat. Nemzeti Tankönyvkiadó, Budapest.

Kiss Jenő 1999: Az anyanyelvoktatás, a nyelvjárások és a nyelvjárási hátterü iskolások. $M a-$ gyar Nyelvör 123: 373-81.

Kontra Miklós 2005. Mi a lingvicizmus és mit lehet ellene tenni? [http://web.unideb.hu/ tkis/ kontra_lingvicizmus.htm - 2019. november 1.]

Kovács Edina 2014. A tanár szakos hallgatók nyelvi attitüdjeinek társadalmi nemi sajátosságai. Anyanyelv-pedagógia 2. [http://www.anyanyelv-pedagogia.hu/cikkek.php?id=514 - 2019. november 11.]

Lakatos Katalin 2010. Kárpátaljai magyar iskolások nyelvi tudata és attitüdje. [Doktori diszszertáció].

Ludányi Zsófia 2016. A nákolástól a „töltelékszavakig”. Gondolatok a(z orvosi) nyelvművelésről és a nyelvi normákról. Magyar Orvosi Nyelv 2: 86-110.

M. Nádasi Mária 2002. Nyelvi hátrány és iskola. Iskolakultúra 6/7: 84-93.

Mackie, Diane M. - Smith, Eliot 2004. Szociálpszichológia. Osiris Kiadó, Budapest.

Nagy Zoltán 2015. Pályán lévő pedagógusok anyanyelvi attitüdjei. In: Pusztai GabriellaMorvai Laura (szerk.): Pálya-modell. Igények és lehetőségek a pedagógus-továbbképzés változó rendszerében. Partium - P.P.S.-Ú.M.K., Nagyvárad-Budapest, 246-7.

Nahalka István 2003. Az oktatás társadalmi meghatározottságának értelmezési keretei. In: Falus Iván (szerk.): Didaktika. Elméleti alapok a tanitás tanulásához. Nemzeti Tankönyvkiadó, Budapest, 38-56. 
Parapatics Andrea 2016. Tények és tapasztalatok a dialektológiai ismeretek tanításáról. In: Czetter Ibolya - Hajba Renáta - Tóth Péter (szerk.): VI. Dialektológiai szimpozion. KeTK, Szombathely-Nyitra, 509-18.

Parapatics Andrea 2019. Dialektusok és modernitás: új módszerekkel a nyelvjárásokról az iskolában. Anyanyelv-pedagógia 1. [http://www.anyanyelv-pedagogia.hu/cikkek. php?id $=772-2019$. november 12.$]$

Presinszky Károly 2011. A szlovákiai magyar nyelvjárásokhoz való viszonyulás. In: Szabómihály Gizella - Lanstyák István (szerk.): Magyarok Szlovákiában VII. kötet: Nyelv. Fórum Kisebbségkutató, Somorja, 193-200.

Réger Zita 1990. Utak a nyelvhez. Nyelvi szocializáció, nyelvi hátrány. Akadémiai Kiadó, Budapest.

Sándor Anna 2009. A nyelvjárási attitüd vizsgálata a nyitrai magyar szakos egyetemisták körében. In: Borbély Anna - Vančo Ildikó - Hattyár Helga (szerk.): Nyelvideológiák, attitüdök és sztereotípiák. 15. Élönyelvi Konferencia. Tinta Könyvkiadó, Budapest, 241-8.

Szabó Tamás Péter 2012. „Kirakunk táblákat, hogy csúnyán beszélni tilos”. A javitás mint gyakorlat és mint téma diákok és tanáraik metanyelvében. Gramma, Dunaszerdahely.

Tódor Erika-Mária 2015. Kié az iskola? Nyelvi tájkép és nyelvhasználati szokások erdélyi magyar tannyelvű iskolákban. In: Benő Attila - Fazakas Emese - Zsemlyei Borbála (szerk.): Többnyelvüség és kommunikáció Kelet-Közép-Európában. XXIV. MANYE. Vol. 11. Erdélyi Múzeum Egyesület, Kolozsvár, 256-66.

Tolcsvai Nagy Gábor 2017. A magyar standard helyzete. In: Tolcsvai Nagy Gábor (szerk.): A magyar nyelv jelene és jövője. Gondolat Kiadó, Budapest, 222-38.

Zoller Melinda 2013, Hátrányos helyzetü tanulók iskolai nehézségei nyelvi szocializációjuk tükrében. [http://rmpsz.ro/uploaded/tiny/files/magiszter/2013/nyar/9.pdf - 2017. április 11.]

\author{
Jánk István \\ egyetemi adjunktus \\ Eszterházy Károly Egyetem \\ https://orcid.org/0000-0003-1327-6412
}

\title{
SUMMARY
}

\author{
Jánk, István
}

\section{The student who speaks a dialect doesn't like grammar? Language attitudes of Hungarian teachers}

The aim of my research was to explore, and prove the existence of, linguistic discrimination. It was implemented by a method I had developed, and involved more than 500 Hungarian teachers and teacher trainees. The research clearly supported the fact that linguistic discrimination and linguistic bias are widespread in pedagogical evaluation. This paper presents my findings on linguistic bias, constituting one part of the overall research.

Keywords: linguistic bias, linguistic disadvantages, pedagogical evaluation, Hungarian teachers. 